\title{
Comparative Analysis of Nine COVID-19 Convalescent Plasma Protocols Registered by Cochrane Central Register of Controlled Trials
}

\author{
Jianli Cui1, ${ }^{1}$ and Youfu $\mathrm{Ke}^{2}$ \\ ${ }^{1}$ Department of Laboratory Medicine, School of Health and Biomedical Sciences, Royal Melbourne Institute of Technology University, Melbourne, Victoria, \\ Australia \\ 2 Clinical Division, School of Chinese Medicine, Hong Kong Baptist University, Hong Kong, China
}

* Corresponding author: Jianli Cui, Clinical Division, School of Chinese Medicine, Hong Kong Baptist University, Hong Kong, China. Tel: +61416858940; Email: cuijianli2015@gmail.com

Received 2020 May 22; Revised 2020 July 17; Accepted 2020 July 31.

\begin{abstract}
Context: Coronavirus disease 2019 (COVID-19) has progressed into a public health emergency of international concern. Passive immunotherapy has been successfully used for the treatment of infectious diseases since the 1890s. It is necessary and constructive to compare and analyze COVID-19 convalescent plasma (CCP) randomized controlled trials (RCTs) to help clinicians to have a potential option for COVID-19.

Evidence Acquisition: In this study, eight databases were searched on May 1, 2020, such as China National Knowledge Infrastructure, PubMed, and Cochrane Library, with the search fields of "Title Abstract Keyword" of "Convalescent plasma AND COVID-19" or " Convalescent plasma AND SARS-CoV-2". The outcome of interest was clinical RCTs for COVID-19.

Results: The search retrieved nine relevant CCP protocols for severe acute respiratory syndrome coronavirus 2 (SARS-CoV-2). All nine trials were randomized, parallel assignment, interventional, clinical treatment studies with NCT04344535, NCT04345289, and NCT04323800 masking and the rest open-label. The estimated enrollment is within the range of 40-1,500 subjects, and five trials will be finished in 2020 as opposed to two in 2021 and two in 2022. Except for NCT04323800 on the prevention of COVID-19, other eight trials will test and verify the effectiveness and safety of CCP for the treatment of COVID- 19.

The used dosage of CCP is within the range of 200-600 mL. NCT04344535, NCT04323800, and NCT04346446 use standard donor plasma in controlled groups in comparison to NCT04348656, NCT04342182, NCT04333251, and NCT04345523 without any positive drug in controlled groups. NCT04332835 adds hydroxychloroquine to both groups, and only NCT04345289 is a six-armed placebo-controlled trial.

Primary and secondary outcome measures are differently expressed in the nine trials. Nevertheless, they can be summarized as $(\rightarrow)$ changes in time, day, and number of a 7-point ordinal scale. There are $(\rightarrow)$ changes in SARS-CoV-2 ribonucleic acid (i.e., viral load), antiSARS-CoV-2 antibody titers (i.e., immunoglobulin M and immunoglobulin G), C-reactive protein, lymphocyte count, lactate dehydrogenase, and interleukin 6 on a specified day or during a specific period.

Conclusion: The nine well-designed RCT trials will establish the efficacy of CCP for the treatment of SARS-CoV-2 from the perspective of evidence-based medicine.

Keywords: Convalescent plasma, COVID-19, Neutralizing antibody, Passive antibody transfer, SARS-CoV-2
\end{abstract}

\section{Context}

Coronavirus disease 2019 (COVID-19) has progressed into a public health emergency of international concern, with grave humanitarian consequences. Up to May 1, 2020, more than 3.2 million patients have been diagnosed with COVID-19 worldwide, and more than 240,000 individuals have died, affecting more than 200 countries and regions (1). At present, the treatment of COVID-19 is limited to supportive care, and there are no approved therapies or vaccines (2). However, there have been a limited number of clinical studies carried out on COVID-19.

Passive immunotherapy has already been successfully used for the treatment of infectious diseases since the 1890s. Convalescent plasma (CP) containing high titer neutralizing antibodies can be used for individuals with specific clinical diseases for the reduction of symptoms and mortality (3). For the treatment of COVID-19, medical studies have been recently applying COVID-19 convalescent plasma (CCP) to this pandemic $(4,5)$. The US Food and Drug Administration has recently recommended CCP for severe acute respiratory syndrome coronavirus 2 (SARS-CoV-2) $(6,7)$.

Several systematic reviews have detected that all completed studies were considered to have bias due to nonrandomized controlled trial methodology (8$10)$, along with some randomized controlled trials (RCTs) registered by Cochrane Central Register of Controlled Trials, which were not finished and did not publish any results. It is necessary and constructive to compare and analyze the CCP protocols to help clinicians to have a potential option for the treatment of COVID-19.

\section{Evidence Acquisition}

Eight databases were searched on May 1, 2020, including China National Knowledge Infrastructure, Wanfang Data, PubMed, Medline, EMBASE, Google 
Scholar, Cochrane Library, and International Clinical Trials Registry Platform, with the search fields of "Title Abstract Keyword" of "Convalescent plasma AND COVID-19" or " Convalescent plasma AND SARSCoV-2". The outcome of interest was the RCT methodology for the treatment of COVID-19.

\section{Results}

The search retrieved nine relevant CCP protocols for SARS-CoV-2 registered this year by the Cochrane Central Register of Controlled Trials (11-19) (Tables 1, 2, 3).

\begin{tabular}{|c|c|c|c|}
\hline $\begin{array}{l}\text { Principal } \\
\text { investigator }\end{array}$ & Elliott Bennett-Guerrero (11) & Shmuel Shoham (12) & Juan Manuel Anaya Cabrera (13) \\
\hline Sponsor & Stony Brook University & Johns Hopkins University & Universidad del Rosario \\
\hline Country & United States & United States & Colombia \\
\hline CT gov accession no. & NCT04344535 & NCT04323800 & NCT04332835 \\
\hline Recruitment status & Enrolling by invitation & Not yet recruiting & Not yet recruiting \\
\hline Research period & April 8, 2020-August 31, 2021 & May 1, 2020-January 2023 & May 1,2020 -December 31,2020 \\
\hline $\begin{array}{l}\text { Estimated } \\
\text { enrollment }\end{array}$ & 500 & 150 & 80 \\
\hline Study type & Interventional (Clinical trial) & Interventional (clinical trial) & Interventional (clinical trial) \\
\hline Allocation & Randomized & Randomized & Randomized \\
\hline Intervention model & Parallel assignment & Parallel assignment & Parallel assignment \\
\hline Masking & $\begin{array}{l}\text { Quadruple (i.e., participant, care } \\
\text { provider, investigator, and outcome } \\
\text { assessor) }\end{array}$ & $\begin{array}{l}\text { Triple (i.e., participant, care provider, } \\
\text { and investigator) }\end{array}$ & None (open-label) \\
\hline Primary purpose & Treatment & Treatment & Treatment \\
\hline Official title & $\begin{array}{l}\text { Convalescent plasma for the reduction of } \\
\text { complications associated with COVID-19 } \\
\text { infection: A randomized trial comparing } \\
\text { the effectiveness and safety of high-titer } \\
\text { anti-SARS-CoV-2 plasma vs. standard } \\
\text { plasma in hospitalized patients with } \\
\text { COVID-19 infection }\end{array}$ & $\begin{array}{l}\text { Convalescent plasma to stem } \\
\text { coronavirus: A randomized blinded } \\
\text { phase II study comparing the efficacy and } \\
\text { safety of human coronavirus immune } \\
\text { plasma vs. control (i.e., SARS-CoV-2 } \\
\text { nonimmune plasma) in adults exposed to } \\
\text { COVID-19 }\end{array}$ & $\begin{array}{l}\text { Convalescent plasma for patients with } \\
\text { COVID-19: A randomized open-label } \\
\text { parallel controlled clinical study }\end{array}$ \\
\hline
\end{tabular}

Inclusion criteria for plasma recipients

1. Age $>18$ years

2. Hospitalized with PCR + COVID-19

\begin{tabular}{|c|c|}
\hline $\begin{array}{l}\text { Exclusion criteria } \\
\text { for Plasma } \\
\text { recipients }\end{array}$ & $\begin{array}{l}\text { 1. Patient within } 14 \text { days of admission } \\
\text { 2. Unable to tolerate } 450-550 \mathrm{~mL} \text { of CCP } \\
\text { 3. Contraindication to transfusion } \\
\text { 4. Pregnant or breastfeeding }\end{array}$ \\
\hline Treatment group & $450-550 \mathrm{~mL}$ of CCP antibody titer $>1: 320$ \\
\hline Control group & $450-550 \mathrm{~mL}$ of standard donor plasma \\
\hline $\begin{array}{l}\text { Primary outcome } \\
\text { measures }\end{array}$ & $\begin{array}{l}\text { 1. The number of days a patient is } \\
\text { receiving invasive mechanical ventilation } \\
\text { during } 28 \text { days after randomization } \\
\text { 2. Patients who die during } 28 \text { days after } \\
\text { randomization are assigned at } 0\end{array}$ \\
\hline
\end{tabular}

Secondary outcome measures
All-cause mortality up to 90 days after randomization
1. Age $>18$ years

2. Close-contact exposure within $96 \mathrm{~h}$ 3. High-risk exposure

4. age $>65$ years with chronic diseases

1. Receipt blood product in the previous 120 days

2. Psychiatric or cognitive illness or recreational drug/alcohol use 3. Confirmed COVID-19

4. Contraindication to transfusion

5. Inability to complete therapy

200-250 mL of CCP antibody titer $>1: 64$

200-250 mL of standard donor plasma

Changes of 7-point ordinal scale at day 28

1. Not hospitalized, no activity limitation

2. Not hospitalized, activity limitation

3. Hospitalized, no requiring $\mathrm{O} 2$

4. Hospitalized, requiring 02

5. Hospitalized, noninvasive ventilation or high flow oxygen

6. Hospitalized, invasive mechanical ventilation or Extracorporeal Membrane Oxygenation 7. Mortality

\begin{tabular}{|c|c|c|}
\hline $\begin{array}{l}\text { Secondary outcome } \\
\text { measures }\end{array}$ & $\begin{array}{l}\text { All-cause mortality up to } 90 \text { days after } \\
\text { randomization }\end{array}$ & $\begin{array}{l}\text { 1. Anti-SARS-CoV-2 titers at days } 0,1,3 \text {, } \\
\text { 7, } 14 \text {, and } 90 \\
\text { 2. Rates of SARS-CoV-2 PCR positivity at } \\
\text { days } 0,7,14 \text {, and } 28 \\
\text { 3. Duration of SARS-CoV-2 PCR positivity } \\
\text { at days } 0,7,14 \text {, and } 28 \\
\text { 4. Peak quantity levels of SARS-CoV-2 } \\
\text { ribonucleic acid at days } 0,7,14 \text {, and } 28\end{array}$ \\
\hline
\end{tabular}

COVID-19: Coronavirus disease 2019

SARS-CoV-2: Severe acute respiratory syndrome coronavirus 2

PCR: Polymerase chain reaction

CCP: Coronavirus disease 2019 convalescent plasma

ICU: Intensive care unit
1. Age range: $18-60$ year 2. Hospitalized with PCR + COVID-19

1. Pregnant or breastfeeding 2. Contraindication to transfusion 3. Critical in ICU (confusion, urea respiratory rate, blood pressure, and 65 years of age or older $<2$;

Sequential Organ Failure Assessment score $>6.6$ )

4. Surgical procedures in the last 30 days 5. Chronic diseases

CCP (500 mL) +hydroxychloroquine (400 mg Bid for 10 days)

Hydroxychloroquine (400 mg Bid for 10 days)

1. Changes in viral load at days $0,4,7,14$, and 28

2. Changes in immunoglobulin $M$ at days $0,4,7,14$, and 28

3. Changes in immunoglobulin $\mathrm{G}$ at days $0,4,7,14$, and 28

1. The proportion of patients in ICU (days 7,14 , and 28)

2. Days of ICU stay (days 7,14 , and 28) 3 . Days of hospitalization (days 7,14 , and 28)

4. The number of patients with mechanical ventilation (days 7,14 , and 28 )

5. Days with mechanical ventilation (days 7,14 , and 28) 6. Clinical status

7. Mortality (days 7, 14, and 28) 


\begin{tabular}{|c|c|c|c|}
\hline Principal investigator & Donald M Arnold (14) & Bart Rijnders (15) & Shiv Kumar Sarin (16) \\
\hline Sponsor & Hamilton Health Sciences Corporation & Erasmus Medical Center & Institute of Liver and Biliary Sciences \\
\hline Country & Canada & Netherlands & India \\
\hline CT gov accession no. & NCT04348656 & NCT04342182 & NCT04346446 \\
\hline Recruitment status & Not yet recruiting & Recruiting & Recruiting \\
\hline Research period & April 27, 2020-December 31, 2020 & April 8, 2020-July 1, 2020 & April 21, 2020-June 30, 2020 \\
\hline Estimated enrollment & 1200 & 426 & 40 \\
\hline Study type & Interventional (clinical trial) & Interventional (clinical trial) & Interventional (clinical trial) \\
\hline Allocation & Randomized & Randomized & Randomized \\
\hline Intervention model & Parallel assignment & Parallel assignment & Parallel assignment \\
\hline Masking & None (open-label) & None (open-label) & None (open-label) \\
\hline Primary purpose & Treatment & Treatment & Treatment \\
\hline Official title & $\begin{array}{c}\text { A randomized open-label trial of } \\
\text { convalescent plasma for hospitalized } \\
\text { adults with acute COVID-19 respiratory } \\
\text { illness (CONCOR-1) }\end{array}$ & $\begin{array}{l}\text { Convalescent plasma therapy from } \\
\text { recovered COVID-19 patients as } \\
\text { therapy for hospitalized patients with } \\
\text { COVID-19 }\end{array}$ & $\begin{array}{l}\text { Efficacy of convalescent plasma therapy in } \\
\text { severely sick COVID-19 Patients: A pilot } \\
\text { randomized controlled trial }\end{array}$ \\
\hline $\begin{array}{l}\text { Inclusion criteria for } \\
\text { plasma recipients }\end{array}$ & $\begin{array}{l}\text { 1. Age } \geq 16 \text { years } \\
\text { 2. Hospitalized with PCR + COVID-19 } \\
\text { 3. Receiving } \mathrm{O}_{2}\end{array}$ & $\begin{array}{l}\text { 1. Age }>18 \text { years } \\
\text { 2. Hospitalized with PCR + COVID-19 }\end{array}$ & $\begin{array}{l}\text { 1. Age }>65 \text { years } \\
\text { 2. Respiratory distress, respiratory rate } \geq 30 \\
\text { beats } / \text { min } \\
\text { 3. Oxygen saturation level less than } 93 \% \\
4 . \mathrm{P}_{\mathrm{a}} \mathrm{O}_{2} / \mathrm{FiO}_{2} \leq 300 \mathrm{mmHg} \\
\text { 5. Lung infiltrates }>50 \% \text { within } 24-48 \mathrm{~h} \\
\text { 6. With comorbidities, such as chronic } \\
\text { obstructive pulmonary disease and chronic } \\
\text { kidney disease } \\
\text { 7. Multiorgan failure }\end{array}$ \\
\hline $\begin{array}{l}\text { Exclusion criteria for } \\
\text { plasma recipients }\end{array}$ & $\begin{array}{l}\text { 1. The onset of symptoms }>12 \text { days } \\
\text { before randomization } \\
\text { 2. Intubated or plan in place for } \\
\text { intubation } \\
\text { 3. Plasma is contraindicated } \\
\text { 4. A decision in place for no active } \\
\text { treatment }\end{array}$ & $\begin{array}{l}\text { Participation in another intervention } \\
\text { trial on the treatment of COVID-19 }\end{array}$ & $\begin{array}{l}\text { 1. Age }<18 \text { years } \\
\text { 2. Patients with known comorbidities } \\
\text { 3. Multiorgan failure or requiring } \\
\text { mechanical ventilation } \\
\text { 4. Pregnancy } \\
\text { hepatitis } \\
\text { 5. Human immunodeficiency viruses and } \\
\text { 6. Obesity: Body mass index }>35 \mathrm{~kg} / \mathrm{m}^{2} \\
\text { 7. Expected life expectancy less than } 24 \mathrm{~h} \\
\text { 8. Failure to give informed consent } \\
\text { 9. Hemodynamic instability requiring } \\
\text { vasopressors } \\
\text { 10. History of allergy to plasma }\end{array}$ \\
\hline Treatment group & $500 \mathrm{~mL}$ of $\mathrm{CCP}$ & $300 \mathrm{~mL}$ of $\mathrm{CCP}$ & $200-600 \mathrm{~mL}$ of CCP \\
\hline Control group & & & $200-600 \mathrm{~mL}$ of random donor plasma \\
\hline $\begin{array}{l}\text { Primary outcome } \\
\text { measures }\end{array}$ & Intubation or mortality in 30 days & Mortality in 60 days or discharge & $\begin{array}{c}\text { The number of patients free of mechanical } \\
\text { ventilation in } 7 \text { days }\end{array}$ \\
\hline $\begin{array}{l}\text { Secondary outcome } \\
\text { measures }\end{array}$ & $\begin{array}{l}\text { 1. Time in hours to intubation from } \\
\text { randomization in } 30 \text { days } \\
\text { 2. In-hospital mortality in } 90 \text { days } \\
\text { 3. Length of ICU stay in } 30 \text { days } \\
\text { 4. Need for Extracorporeal Membrane } \\
\text { Oxygenation in } 30 \text { days } \\
\text { 5. Renal replacement therapy in } 30 \\
\text { days } \\
\text { 6. Myocarditis in } 30 \text { days } \\
\text { 7. Serious adverse events in } 30 \text { days }\end{array}$ & $\begin{array}{c}\text { 1. Hospital stay days } \\
\text { 2. Weaning from oxygen therapy } \\
\text { 3. Mortality } \\
\text { 4. ICU stay days } \\
\text { 5. Decrease in SARS-CoV2 shedding } \\
\text { from airways (airway samples will be } \\
\text { taken on days } 1,3,5,7,10 \text {, and } 14 \text { and } \\
\text { at discharge) } \\
\text { 6. Cytotoxic T lymphocyte and natural } \\
\text { killer cell immunity (blood will be } \\
\text { drawn at days } 1,7 \text {, and } 14 \text { ) } \\
\text { 7. Severe adverse events }\end{array}$ & $\begin{array}{l}\text { 1. Mortality at day } 28 \\
\text { 2. Improvement in } \mathrm{P}_{\mathrm{a}} \mathrm{O}_{2} / \mathrm{Fi} \mathrm{O}_{2} \text { at days } 2 \text { and } 7 \\
\text { 3. Improvement in Sequential Organ Failure } \\
\text { Assessment score at days } 2 \text { and } 7 \\
\text { 4. Duration of hospital stay at day } 28 \\
\text { 5. Duration of ICU stay at day } 28 \\
\text { 6. Requirement of vasopressor at day } 28 \\
\text { 7. Days free of dialysis at day } 28\end{array}$ \\
\hline
\end{tabular}

COVID-19: Coronavirus disease 2019

PCR: Polymerase chain reaction

CCP: Coronavirus disease 2019 convalescent plasma

ICU: Intensive care unit

NCT04344535 in US (11), NCT04342182 in the Netherlands (15), NCT04346446 in India (16), and NCT04345523 in Spain (19) have been recruiting patients; however, NCT04323800 in US (12), NCT04332835 in Colombia (13), NCT04348656 in Canada (14), NCT04345289 in Denmark (17), and NCT04333251 in US (18) have not yet been recruiting patients. Due to the delay between the starting date of the clinical study and date of registration information update, it is temporarily impossible to know whether these five RCT studies have been conducting.

All nine trials are randomized, parallel assignment, interventional, clinical treatment studies with NCT04344535 in US (11) and NCT04345289 in
Denmark (17) in quadruple (i.e., participant, care provider, investigator, and outcome assessor) masking, NCT04323800 in US (12) in triple (i.e., participant, care provider, and investigator) masking, and the rest open-label. The estimated enrollment is within the range of 40-1,500 subjects, and five trials will be finished in 2020 as opposed to two in 2021 and two in 2022. Except for NCT04323800 in US (12) expected to use CCP for the prevention of COVID-19, other eight trials will test and verify the effectiveness and safety of CCP for the treatment of COVID-19. Inclusion and exclusion criteria for CCP are slightly different according to the different study populations and objectives.

The used dosage of CCP is within the range of 200- 


\begin{tabular}{|c|c|c|c|}
\hline Principal investigator & Thomas Benfield (17) & Baylor Research Institute (18) & Cristina Avendaño Solá (19) \\
\hline Sponsor & Hvidovre University Hospital & Baylor Research Institute & Puerta de Hierro University Hospital \\
\hline Country & Denmark & United States & Spain \\
\hline CT gov accession no. & NCT04345289 & NCT04333251 & NCT04345523 \\
\hline Recruitment status & Not yet recruiting & Not yet recruiting & Recruiting \\
\hline Research period & April 20, 2020-June 15, 2021 & April 1, 2020-December 31, 2022 & April 3, 2020-July, 2020 \\
\hline Estimated enrollment & 1500 & 115 & 278 \\
\hline Study type & Interventional (clinical trial) & Interventional (clinical trial) & Interventional (clinical trial) \\
\hline Allocation & Randomized & Randomized & Randomized \\
\hline Intervention model & Parallel assignment & Parallel assignment & Parallel assignment \\
\hline Masking & $\begin{array}{l}\text { Quadruple (i.e., participant, care provider, } \\
\text { investigator, and outcomes assessor) }\end{array}$ & None (open-label) & None (open-label) \\
\hline Primary purpose & Treatment & Treatment & Treatment \\
\hline Official title & $\begin{array}{l}\text { Efficacy and safety of novel treatment options } \\
\text { for adults with COVID-19 pneumonia: A double- } \\
\text { blinded randomized multi-stage six-armed } \\
\text { placebo-controlled trial in the framework of an } \\
\text { adaptive trial platform }\end{array}$ & $\begin{array}{l}\text { Evaluating convalescent plasma } \\
\text { to decrease coronavirus } \\
\text { associated complications: A phase } \\
\text { I study comparing the efficacy and } \\
\text { safety of High-titer anti-Sars-CoV- } \\
2 \text { plasma vs. best supportive care } \\
\text { in hospitalized patients with } \\
\text { interstitial pneumonia due to } \\
\text { COVID-19 }\end{array}$ & $\begin{array}{l}\text { Multicenter randomized clinical trial } \\
\text { of convalescent plasma therapy versus } \\
\text { standard of care for the treatment of } \\
\text { COVID-19 in hospitalized patients }\end{array}$ \\
\hline $\begin{array}{l}\text { Inclusion criteria for } \\
\text { plasma recipients }\end{array}$ & $\begin{array}{l}\text { 1. Age } \geq 18 \text { years } \\
\text { 2. Confirmed COVID-19 } \\
\text { 3. The onset of first experienced symptom no } \\
\text { more than } 10 \text { days before admission }\end{array}$ & $\begin{array}{l}\text { 1. Age } \geq 18 \text { years } \\
\text { 2. Hospitalized within } 3-7 \text { days } \\
\text { from the onset of the illness }\end{array}$ & $\begin{array}{l}\text { 1. Age } \geq 18 \text { years (male or female) } \\
\text { 2. Confirmed COVID-19 } \\
\text { 3. Hospitalization without mechanical } \\
\text { ventilation or high flow oxygen } \\
\text { devices }\end{array}$ \\
\hline $\begin{array}{l}\text { Exclusion criteria for } \\
\text { plasma recipients }\end{array}$ & $\begin{array}{l}\text { 1. Inevitable mortality within } 24 \mathrm{~h} \\
\text { 2. Allergy to study drug } \\
\text { 3. Participation in other drug clinical trials } \\
\text { 4. Pregnant or breastfeeding } \\
\text { 5. eGFR }<30 \mathrm{ml} / \mathrm{min} \\
\text { 6. Severe liver dysfunction } \\
\text { 7. Tuberculosis, hepatitis } \mathrm{B} \text { or C, retinopathy, } \\
\text { maculopathy, neurogenic hearing loss } \\
\text { 8. Absolute neutrophil count }<1,000 \mathrm{~mm}^{3} \\
\text { 9. Alanine aminotransferase }>5 \text { times } \\
\text { 10. Platelet count }<50,000 \text { per } \mathrm{mm}^{3} \\
\text { 11. Chemotherapy or immunomodulatory drugs } \\
\text { within } 30 \text { days before inclusion } \\
\text { 12. Corticosteroids in a dose higher than } \\
\text { prednisolone } 20 \text { mg per day for } 4 \text { weeks }\end{array}$ & $\begin{array}{l}\text { 1. Age }<18 \text { years } \\
\text { 2. Receipt of pooled } \\
\text { immunoglobulin in previous } 30 \\
\text { days } \\
\text { 3. Contraindication to transfusion }\end{array}$ & $\begin{array}{l}\text { 1. Requiring mechanical ventilation } \\
\text { (invasive or noninvasive) or high flow } \\
\text { oxygen devices } \\
\text { 2. More than } 12 \text { days since onset } \\
\text { 3. Participation in any other clinical } \\
\text { trial } \\
\text { 4. Inevitable mortality within } 24 \mathrm{~h} \\
\text { 5. Any incompatibility or allergy to the } \\
\text { administration of human plasma } \\
\text { 6. eGFR }<30 \mathrm{ml} / \mathrm{min} \\
\text { 7. More than } 12 \text { days after onset }\end{array}$ \\
\hline Treatment group & $\begin{array}{c}600 \mathrm{~mL} \text { of CCP infusion + } 1.14 \mathrm{~mL} \text { of saline } \\
\text { injection (placebo) }\end{array}$ & $\begin{array}{l}\text { 1-2 units of CCP antibody } \\
\text { CCP titer }>1: 64\end{array}$ & \\
\hline Control group & $\begin{array}{l}\text { Group A: } 600 \mathrm{ml} \text { of saline infusion (placebo) + } \\
200 \mathrm{mg} / 1.14 \mathrm{~mL} \text { of sarilumab injection } \\
\text { Group B: } 600 \mathrm{ml} \text { of saline infusion (placebo) + } \\
\text { 1.14 mL of saline injection (placebo) } \\
\text { Group C: } 600 \mathrm{mg} \text { of hydroxychloroquine oral for } \\
7 \text { days } \\
\text { Group D: } 4 \mathrm{mg} \text { of baricitinib oral for } 7 \text { days } \\
\text { Group E: } 3 \text { glucose monohydrate capsules for } 7 \\
\text { days (placebo) }\end{array}$ & & \\
\hline $\begin{array}{l}\text { Primary outcome } \\
\text { measures }\end{array}$ & $\begin{array}{l}\text { All-cause mortality or need for invasive } \\
\text { mechanical ventilation in } 28 \text { days }\end{array}$ & $\begin{array}{l}\text { Reduction in oxygen and } \\
\text { ventilation support in } 28 \text { days }\end{array}$ & $\begin{array}{l}\text { Changes of 7-point ordinal scale at day } \\
15\end{array}$ \\
\hline $\begin{array}{l}\text { Secondary outcome } \\
\text { measures }\end{array}$ & $\begin{array}{l}\text { 1. Changes of 7-point ordinal scale at day } 90 \\
\text { 2. Number of days without organ-failure in } 28 \\
\text { days } \\
\text { 3. The mortality rate at days } 7,14,21,28 \text {, and } 90 \\
\text { 4. Length of hospital stay in } 90 \text { days } \\
\text { 5. Days requiring } \mathrm{O}_{2} \text { in } 90 \text { days } \\
\text { 6. Adverse events in } 90 \text { days }\end{array}$ & Not Available/Applicable & $\begin{array}{l}\text { 1. Changes of 7-point ordinal scale at } \\
\text { day } 29 \\
\text { 2. Mortality of any cause at day } 15 \\
\text { 3. Neutralizing antibody activity } \\
\text { against SARS-CoV-2 } \\
\text { viral load at days } 1,3,5,8,11 \text {, and } 29 \\
\text { 4. C-reactive protein, lymphocyte } \\
\text { count, lactate dehydrogenase, D- } \\
\text { dimer, interleukin } 6 \text {, and coagulation } \\
\text { tests at baseline and days } 3,5,8,11 \text {, } \\
\text { 15, and } 29 \\
\text { 5. Adverse events at day } 29\end{array}$ \\
\hline
\end{tabular}

COVID-19: Coronavirus disease 2019

eGFR: Estimated glomerular filtration rate

CCP: Coronavirus disease 2019 convalescent plasma

SARS-CoV-2: Severe acute respiratory syndrome coronavirus 2

600 mL. NCT04344535 in US (11), NCT04323800 in US (12), and NCT04346446 in India (16) use the corresponding amount of standard donor plasma in controlled groups; nevertheless, NCT04348656 in Canada (14), NCT04342182 in the Netherlands (15), NCT04333251 in US (18), and NCT04345523 in Spain (19) are without a positive drug in controlled groups.
NCT04332835 in Colombia (13) adds hydroxylchloroquine (400 mg Bid for 10 days to both groups), and only NCT04345289 in Denmark (17) is a sixarmed placebo-controlled trial.

Primary and secondary outcome measures are differently expressed in the nine trials. However, they can be summarized as $(\rightarrow$ ) changes in time, day, and 
number of 7-point ordinal scale on a specified day or during a specific period (i.e., Not hospitalized, no activity limitation; Not hospitalized, activity limitation; Hospitalized, no requiring $\mathrm{O}_{2}$; Hospitalized, requiring $\mathrm{O}_{2}$; Hospitalized, noninvasive ventilation or high flow oxygen; Hospitalized, invasive mechanical ventilation or Extracorporeal Membrane Oxygenation; Mortality. In addition, there are $(=)$ changes in SARS-CoV-2 ribonucleic acid (i.e., viral load), anti-SARS-CoV-2 antibody titers (i.e., immunoglobulin $M$ and immunoglobulin G), Creactive protein, lymphocyte count, lactate dehydrogenase, and interleukin 6 on a specified day or during a specific period.

\section{Discussion}

The CP has been successfully applied for the treatment of infectious diseases, such as H1N1 (20, 21), severe acute respiratory syndrome (22), H5N1 (23), Ebola (24), and other viral infections. The results of studies have shown that CCP can limit virus reproduction and eliminate SARS-CoV-2 $(4,5)$. However, systematic reviews $(25,26)$ have demonstrated that all reported studies are case reports without a control group with a high risk of bias due to nonrandomized controlled trial methodology $(10,27)$.

Fortunately, the nine well-designed RCTs have been conducting to determine the effectiveness, dosage, and safety of CCP for the prevention and treatment of COVID-19, and whether hydroxylchloroquine is useful for the treatment of COVID-19. As the number of clinical studies in this regard continues to increase, the research protocols may adjust the CCP dosage and other research drugs based on the evidence.

\section{Conclusion}

The nine well-designed RCTs will determine the efficacy of CCP for the treatment of SARS-CoV-2 from the perspective of evidence-based medicine.

\section{Footnotes}

Authors' Contribution: The authors equally contributed to the present study.

Conflict of Interests: The authors declare that there is no conflict of interest.

Funding/Support: The present study was selffunded.

\section{References}

1. Zeng QL, Yu ZJ, Gou JJ, Li GM, Ma SH, Zhang GF, et al. Effect of convalescent plasma therapy on viral shedding and survival in COVID-19 Patients. J Infect Dis. 2020;222(1):38-43. doi: 10.1093/infdis/jiaa228. [PubMed: 32348485].
2. Teixeira da Silva JA. Convalescent plasma: a possible treatment of COVID-19 in India. Med J Armed Forces India. 2020; 76(2):236-37. doi: 10.1016/j.mjafi.2020.04.006. [PubMed: 32296259].

3. Casadevall A, Pirofski LA. The convalescent sera option for containing COVID-19. J Clin Invest. 2020;130(4):1545-8.

4. Sullivan HC, Roback JD. Convalescent plasma: therapeutic hope or hopeless strategy in the SARS-CoV-2 pandemic. Transfus Med Rev. 2020;In Press. doi: 10.1016/j.tmrv.2020.04.001. [PubMed: 32359788].

5. Chen L, Xiong J, Bao L, Shi Y. Convalescent plasma as a potential therapy for COVID-19. Lancet Infect Dis. 2020; 20(4):398-400. doi: 10.1016/S1473-3099(20)30141-9. [PubMed: 32113510].

6. Tanne JH. Covid-19: FDA approves use of convalescent plasma to treat critically ill patients. BMJ. 2020;368:m1256. doi: 10.1136/bmj.m1256. [PubMed: 32217555].

7. Bloch EM, Shoham S, Casadevall A, Sachais BS, Shaz B, Winters $\mathrm{JL}$, et al. Deployment of convalescent plasma for the prevention and treatment of COVID-19. J Clin Invest. 2020;130(6):275765. doi: 10.1172/JCI138745. [PubMed: 32254064].

8. Rajendran K, Narayanasamy K, Rangarajan J, Rathinam J, Natarajan M, Ramachandran A. Convalescent plasma transfusion for the treatment of COVID-19: Systematic review. J Med Virol. 2020;In Press. doi: 10.1002/jmv.25961. [PubMed: 32356910].

9. Xie M, Chen Q. Insight into 2019 novel coronavirus - An updated interim review and lessons from SARS-CoV and MERS-CoV. Int J Infect Dis. 2020;94:119-24. doi: 10.1016/j. ijid.2020.03.071. [PubMed: 32247050].

10. Zhang L, Liu Y. Potential interventions for novel coronavirus in China: a systematic review. J Med Virol. 2020;92(5):479-90. doi: 10.1002/jmv.25707. [PubMed: 32052466].

11. NCT04344535. Convalescent plasma vs. standard plasma for COVID-19. Available at: URL: https://www.cochranelibrary. com/central/doi/10.1002/central/CN-02091604/full; 2020.

12. NCT04323800. Efficacy and safety human coronavirus immune plasma (HCIP) vs. control (SARS-CoV-2 Non-immune Plasma) among adults exposed to COVID-19. Available at: URL: https://www.cochranelibrary.com/central/doi/10.1002/centr al/CN-02089423/full; 2020.

13. NCT04332835. Convalescent plasma for patients with COVID19: a randomized, open label, parallel, controlled clinical study. Available at: URL: https://www.cochranelibrary.com/ central/doi/10.1002/central/CN-02091334/full; 2020.

14. NCT04348656. Convalescent plasma for hospitalized adults with COVID-19 respiratory illness (CONCOR-1). Available at: URL: https://www.cochranelibrary.com/central/doi/10. 1002/central/CN-02091713/full; 2020.

15. NCT04342182. convalescent plasma as therapy for Covid-19 severe SARS-CoV-2 disease (CONCOVID Study). Available at: URL: https://www.cochranelibrary.com/central/doi/10. 1002/central/CN-02091556/full; 2020.

16. NCT04346446. Efficacy of convalescent plasma therapy in severely sick COVID-19 patients. Available at: URL: https://www.cochranelibrary.com/central/doi/10.1002/centr al/CN-02091646/full; 2020.

17. NCT04345289. Efficacy and safety of novel treatment options for adults with COVID-19 pneumonia. Available at: URL: https://www.cochranelibrary.com/central/doi/10.1002/centr al/CN-02089735/full; 2020.

18. NCT04333251. Study testing convalescent plasma vs best supportive care. Available at: URL: https://www.cochraneli brary.com/central/doi/10.1002/central/CN-02091343/full; 2020.

19. NCT04345523. Convalescent plasma therapy vs SOC for the treatment of COVID19 in hospitalized patients. Available at: URL: https://www.cochranelibrary.com/central/doi/10. 1002/central/CN-02091624/full; 2020.

20. Luke TC, Kilbane EM, Jackson JL, Hoffman SL. Meta-analysis: convalescent blood products for Spanish influenza pneumonia: a future H5N1 treatment? Ann Intern Med. 2006;145(8): 599-609. doi: 10.7326/0003-4819-145-8-200610170-00139. [PubMed: 16940336]. 
21. Hung IF, To KK, Lee CK, Lee KL, Chan K, Yan WW, et al. Convalescent plasma treatment reduced mortality in patients with severe pandemic influenza A (H1N1) 2009 virus infection. Clin Infect Dis. 2011;52(4):447-56. doi: 10.1093/cid/ciq106. [PubMed: 21248066].

22. Soo YO, Cheng Y, Wong R, Hui DS, Lee CK, Tsang KK, et al. Retrospective comparison of convalescent plasma with continuing high-dose methylprednisolone treatment in SARS patients. Clin Microbiol Infect. 2004;10(7):676-8. doi: 10.1111/j.1469-0691.2004.00956.x. [PubMed: 15214887].

23. Zhou B, Zhong N, Guan Y. Treatment with convalescent plasma for influenza A(H5N1) infection. $N$ Engl J Med. 2007; 357(14):1450-1. doi: 10.1056/NEJMc070359. [PubMed: 17914053].

24. Dean CL, Hooper JW, Dye JM, Zak SE, Koepsell SA, Corash L, et al. Characterization of Ebola convalescent plasma donor immune response and psoralen treated plasma in the United States. Transfusion. 2020;60(5):1024-31. doi: 10.1111/trf. 15739. [PubMed: 32129478].

25. Rubin R. Testing an old therapy against a new disease: convalescent plasma for COVID-19. JAMA. 2020;In Press. doi: 10.1001/jama.2020.7456. [PubMed: 32352484].

26. Dzik S. COVID-19 convalescent plasma: now is the time for better science. Transfus Med Rev. 2020;In Press. doi: 10.1016/j.tmrv.2020.04.002. [PubMed: 32359789]

27. Pang J, Wang MX, Ang IY, Tan SH, Lewis RF, Chen JI, et al. Potential rapid diagnostics, vaccine and therapeutics for 2019 Novel Coronavirus (2019-nCoV): a systematic review. J Clin Med. 2020;9(3):623. doi: 10.3390/jcm9030623. [PubMed: 32110875] 